This item was submitted to Loughborough's Research Repository by the author.

Items in Figshare are protected by copyright, with all rights reserved, unless otherwise indicated.

\title{
Spontaneity and international marketing performance
}

PLEASE CITE THE PUBLISHED VERSION

https://doi.org/10.1108/IMR-06-2014-0199

\section{PUBLISHER}

(C) Emerald

\section{VERSION}

AM (Accepted Manuscript)

\section{PUBLISHER STATEMENT}

This work is made available according to the conditions of the Creative Commons Attribution-NonCommercialNoDerivatives 4.0 International (CC BY-NC-ND 4.0) licence. Full details of this licence are available at: https://creativecommons.org/licenses/by-nc-nd/4.0/

\section{LICENCE}

CC BY-NC-ND 4.0

\section{REPOSITORY RECORD}

Souchon, Anne, Paul Hughes, Andrew M. Farrell, Ekaterina Nemkova, and Joao Oliveira. 2016. "Spontaneity and International Marketing Performance". Loughborough University. https://hdl.handle.net/2134/20766. 


\section{Emerald International Marketing}

Review

\section{Spontaneity and International Marketing Performance}

\begin{tabular}{|r|l|}
\hline Journal: & International Marketing Review \\
\hline Manuscript ID & IMR-06-2014-0199.R3 \\
\hline Manuscript Type: & Original Article \\
\hline Keywords: & $\begin{array}{l}\text { Exporting, International marketing, Spontaneity, Performance, Decision- } \\
\text { making, Contingency theory }\end{array}$ \\
\hline \multicolumn{2}{|l}{} \\
\hline
\end{tabular}

\section{SCHOLARONE ${ }^{m}$ \\ Manuscripts}




\begin{abstract}
Purpose - The purpose of this paper is to ascertain how today's international marketers can perform better on the global scene by harnessing spontaneity.

Design/methodology/approach - We draw on contingency theory to develop a model of the spontaneity-international marketing performance relationship, and identify three potential moderators, namely strategic planning, centralization, and market dynamism. We test the model via structural equation modeling with survey data from 197 UK exporters.

Findings - The results indicate that spontaneity is beneficial to exporters in terms of enhancing profit performance. In addition, greater centralization and strategic planning strengthen the positive effects of spontaneity. However, market dynamism mitigates the positive effect of spontaneity on export performance (when customer needs are volatile, spontaneous decisions do not function as well in terms of ensuring success).

Practical implications - Learning to be spontaneous when making export decisions appears to result in favorable outcomes for the export function. To harness spontaneity, export managers should look to develop company heuristics (increase centralization and strategic planning). Finally, if operating in dynamic export market environments, the role of spontaneity is weaker, so more conventional decision-making approaches should be adopted.

Originality/value - The international marketing environment typically requires decisions to be flexible and fast. In this context, spontaneity could enable accelerated and responsive decisionmaking, allowing international marketers to realize superior performance. Yet, there is a lack of research on decision-making spontaneity and its potential for international marketing performance enhancement.
\end{abstract}

Keywords: International marketing; Spontaneity, Performance; Decision-making; Exporting; Contingency theory. 


\section{Introduction}

The international environment is characterized by the interdependence of markets, intensified competition, fragmented customer needs, and rapid change. Conventional wisdom argues that formal planning enables a company to align to the external environment. Formal planning is often defined as a deliberate decision-making process of identifying clear objectives, analyzing the environment, and assessing multiple alternatives in order to make optimal decisions based on market forecasts (Bailey et al., 2000). However, rapid change and increased environmental uncertainty make accurate predictions difficult. In this context, international marketers such as exporters (Nemkova et al., 2012) and entrepreneurs (Busenitz and Barney, 1997), including those involved in international trade (Dibben et al., 2003), and born global firms (Knight and Liesch, 2016), "are confronted with high levels of unpredictability and ambiguity combined with a considerable time pressure - a really challenging environment for decisions" (Nummela et al., 2014, p. 528). Consequently, there is growing evidence that such organizations increasingly prefer alternative decision-making processes to planning. For example, the use of heuristics, emergent decision-making and opportunistic behavior may all be desirable (Berg, 2014; Olson, 1986).

Contemporary thinking in decision-making recognizes that more emergent rather than deliberate approaches, advocated by Mintzberg as far back as the 1970s, are now essential to the development of agile organizations, particularly those that operate in dynamic environments. Scholars claim that the decision-making process is rarely actualized as formal planning since managers actively question their own ability to predict long-term market changes (Pina E Cunha, 2007; Nutt, 2008; Dew et al., 2009). Decisions are now made in a more flexible and spontaneous fashion to allow for greater responsiveness (Tayur, 2013) and international success (Nemkova et 
al., 2015). While the need to consider alternative approaches to planning has long been recognized, research in this area is fragmented. Attention is mostly focused on the relationships between emergent decision-making approaches (e.g. improvisation, intuition) and the speed of the decision-making process or responsiveness to the market. At the same time, the direct impact on firms' international performance is often overlooked.

We suggest that under complex environmental conditions the ability to generate timely, rather than optimal, decisions is becoming increasingly important to firm success. This highlights the construct of spontaneity which is defined as the ability to make decisions in the moment (Vera and Crossan, 2005). Spontaneity "allows people to react to events as they unfold, or to be able to continue to move forward despite the unexpected" (Gesell, 2005, p. 4). Spontaneity increases the speed at which decisions are made and implemented, consolidating first-mover advantages when fast decision-making is essential (Moorman and Miner, 1998), and permitting timely adaptation to inconsistent market conditions (Chelariu et al., 2002). Internationally-active businesses often operate in complicated market settings caused by, for example, political unrest, fluctuating exchange rates, and cultural heterogeneity. Spontaneity, then, can provide powerful means for firms to enhance international performance. Currently, theories for maximizing financial and other outcomes of spontaneity are underdeveloped (Vera and Crossan, 2005). While spontaneity has received some attention in the literature (mostly as a facet of improvisation), its impact on firms' international performance remains underexplored. Moreover, while there is evidence that spontaneity can lead to positive outcomes for the company (e.g. responsiveness), some concerns have been raised regarding the unpredictable nature of spontaneity. For instance, it has been argued that spontaneity lowers companies" "protection" against mistakes and decreases the effectiveness of decision-making processes by making them chaotic (Nemkova et al., 2015). 
The objectives of this study are to: (1) develop an understanding of the potential benefits and drawbacks of spontaneity for international marketing decisions; and (2) understand the conditions under which spontaneity is most valuable, and most harmful. Using contingency theory we investigate the impact of external and internal factors on the spontaneity-international marketing performance relationship. To this end, we develop a model of spontaneity and its relationship with international marketing performance, and test this model on a sample of UK exporters.

The theoretical contributions of this work are twofold. First, we contribute to knowledge of decision-making drivers of firms' international performance. Being a core management function, decision-making can directly influence performance (Nemkova et al., 2012). However, while the performance outcomes of deliberate decision-making approaches (e.g. planning) have been extensively researched, the relationship between more emergent decision-making (e.g. spontaneity) and international marketing performance requires further investigation. Second, we develop a better understanding of the conditions under which spontaneity helps or harms the international performance of the firm. Previous studies noted that spontaneity can contribute to, or detract from, a firm's international success. However, the conditions under which this occurs remain underexplored.

From a managerial perspective, the findings of the present study act as a guide for assessing how and when international marketers should increase or decrease spontaneity. A contingency perspective is adopted (Gruber, 2007), identifying the contextual factors which render spontaneity necessary versus dysfunctional and, as a result, managers will know when to encourage or discourage spontaneous decision-making. The lack of empirical work linking spontaneous decision-making to performance means that no recommendations currently exist: there are no practical guidelines to help managers adopt effective spontaneity or avoid harmful spontaneity. 
In what follows, we present the theoretical underpinnings of the study and explain how contingency theory informs the conceptual model. We then explain the development of the model. Subsequently, we discuss our methodology and present an outline and discussion of results. We conclude with an examination of implications, limitations, and avenues for further research.

\section{Theoretical underpinnings}

Hambrick and Lei (1985) explain that three schools of thought underpin business research: situation-specific, universal, and contingency. Situation-specific views compile a detailed understanding of each firm's situation, with decision-making analyzed within the context of infinite unique variables. At the other extreme, universalists believe that strategy follows universal laws applicable to all contexts. The contingency view specifies that the effectiveness of decision-making depends on organizations' competitive and structural settings and "focuses on the performance effects of "fit"" (Sirmon and Hitt, 2008, p. 1376). It is a compromise in that while decision outcomes depend on circumstances, there are also categories of settings for which generalizations are appropriate. It stands to reason that researchers can best contribute to knowledge through the contingency view, because "unless one is willing to admit the possibility that there exists some strategy or set of strategies which are optimal for all businesses (corporations) no matter what their resources and no matter what environmental circumstances they face - an assumption that is inconsistent with all research studies on business (corporate) strategy conducted to date - any theory of business (corporate) strategy must be a contingency theory" (Hofer, 1975, pp. 785-786). 
There are three additional reasons for adopting this lens. First, contingency theory is not only central to the development of business research in general, it is also increasingly relevant to studies of international marketing performance (Katsikeas et al., 2000). For instance, Cadogan et al. (2009) found that the optimal value of export market-oriented behaviors is contingent on market dynamism and internationalization. Similarly, Boso et al. (2013) show that the optimal value of firm innovativeness for international marketers is contingent on competitive intensity and market dynamism, networking capability, and organicity. Second, there is already some evidence that the outcomes of spontaneity are conditional (c.f. Mascitelli, 2000; Moorman and Miner, 1998). Third, international marketing studies anchored in contingency theory have focused on describing mediation effects in the structure-decision-making-performance relationship (Hultman et al., 2009). Given the importance of fit to contingency theory, greater contribution to knowledge can actually be achieved by modeling the relationships as fit-asmoderation (Venkatraman, 1989).

The key to applying fit-based contingency theory to a model of decision-making lies in the identification of key contingencies. Internationalization is a firm's strategic response to the interplay of internal and external factors (Sousa et al., 2008), so internal and external contingencies should be considered (Hultman et al., 2009). Contingency theory suggests that the marketing activities-performance relationship is dependent upon (a) the nature of the environment; (b) the structure of the organization, and; (c) the nature of the task (Ruekert et al., 1985). The nature of the international environment ranges from turbulent to stable (Cadogan et al., 2009). A turbulent environment may render spontaneity desirable to speed up decisionmaking so the organization stays abreast of environmental changes. Firm structure is often conceptualized and operationalized along the centralization continuum (Auh and Menguc, 2007). Drawing on Mascitelli (2000), successful spontaneity requires the cooperation, interaction, and 
information flow afforded by more formal structures. Finally, the nature of the decision-making task revolves around deliberation and emergence. Decision-making can occur rationally through strategic planning or the decision can emerge from experience and intuition (Mintzberg, 1978). Spontaneity does not occur in a vacuum as both planning and spontaneity are often found in firms (Chelariu et al., 2002; Nemkova et al., 2012), so the interplay between the two is a more likely conduit to success than either in isolation. Simply put, 'either/or' situations are not representative of strategic decision-making in organizations today.

International marketing performance is the outcome of a firm's decision-making regarding internationalization activities. While such a construct is multidimensional, the dimensions used to measure it vary from study to study. For example, a literature review by Sousa (2004) reveals wide-spread use of sales-, profit-, and market-related dimensions. Katsikeas et al. (2000), on the other hand, distinguish between effectiveness (the fulfilment of export objectives), efficiency (the ratio of export outcomes to the inputs required to achieve them), and adaptiveness (the ability to respond to environmental conditions) dimensions, and report on the more common usage of the effectiveness dimension. For this study, we focus on profit-based effectiveness, as efficiency and adaptiveness would be expected to contribute to this.

\section{Conceptual model}

We propose a conceptual framework, anchored in contingency theory, linking spontaneity to international marketing performance. In line with classical contingency theory (e.g. Donaldson, 2001), we model structural (internal) and environmental (external) variables as moderators of this relationship in Figure 1. These moderators are discussed below. 
Spontaneity is a management resource that embodies the ability to operate "in the moment". Firms that can operate spontaneously find that they can deal with unanticipated events as they occur, and can think on their feet. In this context, international marketing is different to domestic trading as the foreign environment is more complex, with more unexpected problems with limited time to resolve them (Raven et al., 1994). The ability to be spontaneous is an important antidote to complex environments in general and international markets in particular (Nemkova et al., 2012). Firstly, spontaneity implies greater levels of flexibility in decision-making. As such, it allows for faster decisions (Chelariu et al., 2002), enhancing competitiveness and responsiveness to customers' needs (Nemkova et al., 2015). Second, spontaneity is a route to creating unpredictable products and services (Brown and Eisenhardt, 1998) and can help generate unexpected solutions to problems (Pina E Cunha et al., 2003). Third, according to Hmieleski et al. (2013), the implementation of decisions in the moment enables the firm to explore market opportunities and can positively influence firms' economic performance. We also expect international marketing performance to benefit from spontaneity as a result of the rapid adaptation to fluctuating market demands that it fosters. In this context, we propose the following hypothesis:

H1. The relationship between spontaneity and international marketing performance is positive.

Bailey et al. (2000, p. 153) define planning as "an intentional process involving a logical, sequential, analytic and deliberate set of procedures. Based on this assessment, the option is chosen that is judged to maximize the value of outcomes in relation to organizational goals. The selected option is subsequently detailed in the form of precise implementation plans, and systems 
for monitoring and controlling the strategy are determined”. In the absence of strategic planning, there is the danger that spontaneity could lead to random activities that are at odds with organizational goals, resources, skills, and capabilities. Accordingly, under low levels of strategic planning, higher spontaneity may result in actions that emerge with little consideration of their place within the firm's overarching strategy. However, if management can act spontaneously within a framework of planned strategy or, at least, with planned strategy informing spontaneous activity, it is more likely that spontaneous decisions will take advantage of organizational resources, leading to the successful implementation of strategy. Thus, spontaneous decisionmaking in the context of greater planning levels is expected to contribute more strongly to international marketing performance. Thus:

H2. Strategic planning positively moderates the relationship between spontaneity and international marketing performance: the greater the level of strategic planning in the firm, the stronger the positive relationship between spontaneity and international marketing performance.

Centralization is the extent to which authority is concentrated at higher levels of the organization (Menon et al., 1996). In highly decentralized export organizations, decision-making can occur at numerous touch points: for example, individual export executives can make decisions that affect the firm and its success independently and autonomously. This situation brings with it dangers, such as the possibility that spontaneity, often driven by the need to make rapid decisions in the face of complex and unexpected environmental shifts, can lead to decisions that adversely affect the firm's success - by, for example, making choices that contradict, clash, and/or are not aligned with the planned strategies of the firm. Thus, even under the presence of higher strategic planning 
levels, increasing spontaneity can boost the chances of random actions by individual decisionmakers, thereby undermining the role of planning. Centralization can mitigate this potential problem, by ensuring that the decision-making personnel who act spontaneously are not overly dispersed across the organization. By containing spontaneous decision-making activity within a narrower social system, the chances that spontaneous decisions will be excessively risky or strategically misaligned are reduced, while the ability to coordinate and control the implementation of these decisions is increased (Ruekert et al., 1985). Centralization, therefore, may act to temper the potential shortcomings of spontaneity, and so spontaneous decision-making in the context of higher levels of centralization is predicted to contribute more strongly to international marketing performance. Hence:
H3. Centralization positively moderates the relationship between spontaneity and international marketing performance: the greater the level of centralization in the firm, the stronger the positive relationship between spontaneity and international marketing performance.

\begin{abstract}
Export market dynamism captures the pace of change in export customers' needs and wants (e.g. Cadogan et al., 2005). Greater spontaneity levels imply greater ability on the part of managers to respond to changes in the environment (c.f. Dibrell et al., 2007) and to initiate responses "just-in time" when necessary (Weick, 1998). Such characteristics become increasingly important as the speed of change in export customers' needs and wants becomes greater. For example, as export market dynamism rises, spontaneous decisions are likely to be more beneficial as they allow organizations to respond more rapidly to fluctuating customer needs (Jaworski and Kohli, 1993). Indeed, the ability to act fast and pre-empt competition is a central tenet of first mover-
\end{abstract}


advantages, which are often regarded as being important for building long-term profits (Zhara and Garvis, 2000). Accordingly, we suggest that spontaneity is likely to become more useful for international marketing performance as export market dynamism rises. Therefore:

\begin{abstract}
H4. Market dynamism positively moderates the relationship between spontaneity and international marketing performance: the greater the level of market dynamism the firm experiences, the stronger the positive relationship between spontaneity and international marketing performance.
\end{abstract}

\title{
Methodology and data collection
}

A survey of export decision-makers in 197 UK firms was undertaken. All measures were sourced from existing literature (see Table 3). Spontaneity was measured with three, spontaneity-specific, items from Vera and Crossan’s (2005) improvisation scale. Planning items were drawn from Bailey et al. (2000) and export centralization from Cadogan et al. (2005). Market dynamism was captured with items from Jaworski and Kohli (1993). International marketing performance was measured as export profit effectiveness with items taken from Cadogan et al. (2005) and Langerak et al. (2004). All items were 7-point Likert-type scales.

Following typical international marketing studies (c.f. Cadogan et al., 2001; Cadogan et al., 2003; Hultman et al., 2011; Katsikea et al., 2007; Sousa et al., 2008), we included three control variables which could influence international marketing performance, namely company size (measured via the firm's total number of full-time employees), export experience (the number of years exporting), and the overall level of competitive intensity faced by the firm in its export activities (gauged using items from Jaworski and Kohli, 1993). We also included instrumental 
variables to test for and mitigate potential endogeneity. These were export memory (Souchon et al., 2012) and mechanistic structure (Bourgeois et al., 1978).

The questionnaire was pre-tested using protocols, debriefing, and a pilot study. Upon revision, it was sent to a random sample of 1,207 eligible exporters drawn from a Dun \& Bradstreet database. We followed Dillman's (2000) method for survey administration. A total of 197 responses were received, for a response rate of $16.32 \%$, commensurate with response rates from other export studies (Lukas et al., 2007; Theodosiou and Katsikea, 2013). Our survey approach models prior work in international marketing (Bello et al., 2010) in that we used a single export decision-maker from each firm. This approach tends to have low susceptibility to bias in international research (Rindfleisch et al., 2008).

\section{Results and discussion}

\section{Measure validation}

We used LISREL 8.80 to run Confirmatory Factor Analysis (CFA) and Structural Equation Modeling (SEM). We ran a CFA with all measurement items. We used maximum likelihood estimation, and assessed model fit using common indicators (Diamantopoulos and Siguaw, 2009). The fit indices demonstrate that the CFA provided a good fit with the data (Table 1).

\section{"Insert Table 1 about here"}

Attention was then given to potential common method variance (CMV) problems. First, we guarded against potential common method bias by taking procedural measures at the questionnaire development stage following recommendations given by Podsakoff et al. (2003). We attenuated for any potential CMV bias by using an instrumental variable technique (Antonakis et al., 2010). The two instruments used were export memory and mechanistic 
structure. The instrumental variable approach suggests that common method biases do not explain relationships between study constructs. The CFA output was used to calculate the composite reliability (minimum 0.77 ) and average variance extracted (minimum 0.53 ) for each construct. Discriminant validity was assessed in two ways. First, we used a $\chi^{2}$ difference test for each possible pair of constructs, forcing each pair of constructs to fit a single-factor model and comparing the fit with a two-factor model (Anderson and Gerbing, 1988). Even accounting for the large number of $\chi^{2}$ tests performed (c.f. Vorhees et al., 2016), the two-factor model always provided a better fit with the data than the single-factor model. Second, we compared the average variances extracted (AVEs) with the squared correlations from the standardized PHI matrix. The lowest AVE was 0.53 (market dynamism) and the largest squared correlation between any two constructs was 0.21, indicating good discriminant validity (Fornell and Larcker, 1981).

\section{Structural Model}

The second stage of the analysis involved running the structural model with instrumental variables. Our approach here follows the recommendations of Venkatraman (1989) in analyzing fit-as-moderation relationships. Specifically, we eschew sub-group analyses or split sample approaches in favor of a moderated structural equation model because the performance outcome is determined by the interactions between the predictor and the moderators (Sharma et al., 1981; Venkatraman, 1989).

We mean-centered the raw scores of antecedent variables to reduce potential problems of multicollinearity linked to the inclusion of the interaction terms (Aiken and West, 1991) required for the assessment of moderating effects. Three interaction terms were created by the products of spontaneity with: strategic planning; centralization, and; market dynamism. In addition, the latter moderating variables were also inserted into the structural equations as main effects following 
statistical convention for hierarchical testing of interaction effects (Sharma et al., 1981). In line with Germann et al. (2013), we also computed quadratic terms (both for the main effect of spontaneity and for the moderating effects), and included them in the model to control for potential non-linear effects. We used Ping's (1995) approach for estimating interactions between latent constructs in structural equation models. This procedure is recommended in order to lessen model complexity since our model comprised a number of interaction effects (Jaccard and Wan, 1996). Single indicants were therefore computed for all multi-item latent variables (except for export profit effectiveness) by averaging the corresponding measurement items. Export profit effectiveness was modeled as a first-order latent variable comprised of three items. We set the error variances of the single indicants associated with the latent variables to $\left[(1-\alpha) \cdot \sigma^{2}\right]$ (Jöreskog and Sörbom, 1993), where $\alpha$ corresponds to the construct reliability and $\sigma$ to the standard deviation of the single indicant. Following established guidelines (Song et al., 2005) we used the factor loading and the error variance estimates obtained from the main effects model to compute loadings and error variances of the single indicants corresponding to the quadratic and interaction terms. We ran two models, a model where endogeneity is assumed not to exist and a model where endogeneity is presumed and controlled for. The $\chi^{2}$ difference between those two models was not statistically significant, suggesting that endogeneity is not a concern (Antonakis et al., 2010).

In addition, we ran two models, namely a constrained model and an unconstrained model. In the constrained model we allowed only the direct effects to be estimated freely. Accordingly, we set interaction terms at zero. In the unconstrained model we allowed all effects to be estimated freely. Although the decrease in $\chi^{2}$ accrued from moving from the constrained to the unconstrained model was not statistically significant, $\left(\Delta \chi^{2}=13.11 ; \Delta\right.$ d.f. $\left.=7, p>.05\right)$, the unconstrained model explained an additional $10 \%$ of variance in the dependent variable (the $R^{2}$ 
statistics of the constrained and unconstrained models were $24 \%$ and $34 \%$, respectively).

Additionally, the unconstrained model exhibited better fit statistics across all key fit indicators in comparison to the constrained model. Table 1 exhibits the statistics of the measurement and structural models, and the correlations among constructs. As shown in Table 1, the results of the unconstrained model indicate excellent fit with the data, as indicated by non-significant $\chi^{2}(35.60$, p > 0.05), RMSEA (0.04), NNFI (0.96), and CFI (0.99). Accordingly, the unconstrained model was used for the purposes of hypothesis testing. Table 2 shows the t-values and coefficients associated with each relationship.

\section{"Insert Table 2 about here"}

Given the presence of multiple moderating and quadratic effects in our model, we assess it in its entirety in order to draw conclusions on the study hypotheses (Kam and Francese, 2007). To provide insights into the hypothesis testing, we use a graphical method which integrates the path coefficients estimated in Table 2. Precisely, adopting one-tailed tests to determine whether to accept or reject model coefficients (because the model hypotheses are directional, predicting positive or negative links with export performance), and using the unstandardized coefficients of our model, we plot graphical representations of the relationship between spontaneity and export performance under low and high values of the moderators (see Figure 2).

\section{"Insert Figure 2 about here"}

Examination of Figure 2 reveals that spontaneity has a positive impact on performance in all scenarios. Hence, $\mathrm{H} 1$ is corroborated. We also found support for $\mathrm{H} 2$ which anticipates that strategic planning increases the strength of the link between spontaneity and international marketing performance (see section A of Figure 2). Furthermore, as depicted in section B of Figure 2, the patterns of relationships are consistent with the argument that centralization strengthens the spontaneity-performance relationship, in support of H3. Surprisingly, our results 
were not consistent with $\mathrm{H} 4$, as export market dynamism weakens the link between spontaneity and performance (see section $\mathrm{C}$ of Figure 2).

\section{Discussion}

Given the increasingly complex international environment in which firms operate, choosing the right decision-making approach for given situations is an area of growing interest. We hypothesized that spontaneity can improve international performance, and that strategic/structural characteristics, and market dynamism would moderate such a relationship. Findings confirmed the importance of spontaneity to international marketing performance. Thus, while the accepted norm for international decision-making is the planning approach (Lukas et al., 2007), managers who make spontaneous decisions reap significant benefits. For example, spontaneity enables responses to customer demands to be faster and more flexible, offering instant solutions to queries, generating greater customer satisfaction, competitive advantage, and increased sales. However, international marketers need to be context-aware as the positive effect of spontaneity on international marketing performance is stronger when the organization undertakes greater levels of strategic planning, is more centralized, and market dynamism is lower.

Strategic planning was found to play a positive moderating role on the spontaneityinternational performance link. Our results suggest that spontaneous decision-making in the presence of planning is more likely to lead to the successful implementation of international marketing strategy. Such findings seem to validate the literature in that success in complex environments requires both planning and more flexible decision-making (Da Cunha et al., 2001). This seems more representative of decision-making in international marketing as it is implausible to suggest that managers plan all possible decisions and predict all possible contingencies without 
needing to spontaneously react to events as they occur. Similarly, while spontaneity itself is beneficial for international performance, it is more likely that having some control and focus (as provided by strategic planning) better enables organizations to capture rewards from spontaneous behavior.

Findings also suggest that the link between spontaneity and international marketing performance is positively moderated by centralization. This supports the notion that centralization acts as a monitoring mechanism for spontaneity, ensuring the latter does not encourage decisions which are excessively risky or misaligned with the firm's strategy. Hence, our study suggests that centralization acts as a supporting structure for spontaneity.

Contrary to expectations, export market dynamism is found to weaken the positive link between spontaneity and international marketing performance. A possible explanation for this could be that greater levels of export market dynamism render the task of managing international marketing operations more complex. Hence, while spontaneity can allow organizations to respond rapidly to changing market conditions, such benefit may be overshadowed by enhanced coordination problems. It can be concluded that spontaneity has inherent dangers that managers should compensate for by having alternative decision-making processes in place. Logically, then, research attention needs to be directed toward examining the balance of decision-making modes that best suits organizations operating in turbulent market conditions. Given that effective coordination is critical to attain superior performance in dynamic environments (Han et al., 1998), spontaneity becomes less beneficial for firms under greater levels of market dynamism.

The present study offers practical insights for managers of internationalizing firms. Our findings indicate that spontaneity is a crucial predictor of international marketing performance. Hence, managers ought to increase the levels of spontaneity that characterize decision-making processes which concern their firms' international marketing activities. Furthermore, the pursuit 
of greater levels of spontaneity should be coupled with investments in higher strategic planning, as the latter circumvents the potential shortcomings of spontaneity and increases the chances that spontaneous decisions effectively use organizational resources. In addition, higher levels of spontaneity ought to be combined with a more centralized structure, as centralization acts as a monitoring mechanism for spontaneity, guarding against its potential weaknesses. Managers should also note that spontaneity becomes less beneficial for international marketing performance under higher levels of market dynamism. As such, investments in greater levels of spontaneity should be pursued more/less under conditions of lower/higher market dynamism.

\section{Conclusions}

This study makes several contributions to international marketing and management theory. It is, to the authors' best knowledge, the first to specifically address the spontaneity-international performance relationship. In addition, this is the first attempt to investigate critical strategic/structural/environmental contingencies that affect the usefulness of spontaneity in terms of improving international marketing performance. Our findings build on the theoretical debate surrounding structure and strategy. Strategy researchers advocate a strategy-before-structure approach (Chandler, 1962). Underpinned by a fit-as-moderation perspective (Venkatraman, 1989), our study suggests that strategic, structural, and environmental conditions play a critical role in shaping the spontaneity-performance relationship for international firms. Hence, such conditions should be monitored, in order to ensure that spontaneity operates in a safe environment and, relatedly, is appropriate in light of the internal and external contexts of the firm. Spontaneity boosts international marketing performance when the organization undertakes 
greater levels of strategic planning, is more centralized, and faces lower levels of market dynamism.

Spontaneity is particularly beneficial for international marketing performance when companies adopt a more systematic approach to decision-making, as greater levels of strategic planning protect against less well-thought out spontaneous decisions which can lead to random activities that are not aligned with organizational goals, resources, skills, and capabilities. Strategic planning also assists management in taking advantage of organizational resources when adopting spontaneous decision-making processes. In addition, the positive effect of spontaneity on international marketing performance is boosted when firms have a more centralized structure, as centralization acts as a monitoring mechanism, preventing excessive decisions that may be brought about by enhanced spontaneity levels, thus mitigating the potential shortcomings of spontaneity. We also find that more stable markets constitute a safer environment for spontaneity, as under greater levels of market dynamism spontaneity may stifle coordination, rendering its effect on performance less positive.

This study suffers from the traditional limitations associated with work of this nature. A larger sample would have been beneficial, and the cross-sectional nature of the study reduces the strength of the causal claims that can be made as a result of the research undertaken. More rigorous, causal research designs (e.g. longitudinal studies, experiments) are required to formally confirm the causal mechanisms we propose. The specific context of the study also warrants caution if attempting to generalize findings more widely. Performance measures of the organizations which were sampled could have been linked to more objective data, such as share prices. Such data could then enable model testing to be nested within firms who are, for example, low, medium or high performers based on share price indexing, or firms displaying low versus 
high share price volatility. Finally, we did not consider survival bias, so our sample may display a bias towards more successful firms simply because respondents are still in business.

There is much scope for further research into the area of spontaneity. First, international managers are expected to monitor market developments and design responses. In many cases, this process is undertaken in a context of competing goals, requests for attention from different international markets, limited resources, and information overload. It is often argued that in such circumstances, managers will be constrained in decision-making through bounded rationality (Simon, 1957). Managers may reduce information processing and rely on simplified models of reality to make decisions. This may lead to suboptimal or rash action where being spontaneous may be to the detriment of the firm in the longer term. For instance, actions used in the past may be repeated at the expense of developing and executing new responses (Hambrick et al., 1993), rendering international experience a negative factor. In this context, a potentially fruitful research avenue could be to adopt a longitudinal design to study spontaneity and delineate the factors that contribute to its success over time. Indeed, Varadarajan and Jayachandran (1999) suggest that the analysis of spontaneity can examine the temporal sequence in which actions occur in firms. As spontaneous strategy formulation and implementation occur simultaneously, investigating the process of spontaneity over time is likely to yield significant understanding of this complex phenomenon.

Second, a socio-cognitive approach could be adopted to assess the relationship between learning and spontaneity. Leybourne (2006) found that organizational members can be trained to think on their feet by learning from success and failure. Members thus develop a repertoire of effective routines from which to choose when being spontaneous. It is therefore no surprise that consultancy agencies which specifically train managers to be more spontaneous and creative are multiplying (e.g. Agility Consulting and Training, 2016). 
Third, spontaneity may also have a role to play in service provision. A service orientation has become a key differentiator of firms in competitive environments, with both manufacturing and service firms implementing service business orientations with a view to increasing performance (Antioco et al., 2008). Yet, the core trade of a manufacturing firm remains its physical goods, which result from engineer-driven production. On the other hand, the production of a service is more fluid and malleable, and therefore easier to adapt through spontaneity. Against this background, future research may involve comparing manufacturers and service providers in terms of absolute levels and outcomes of spontaneity. If stronger performance outcomes of spontaneity are observed within pure service industries, lessons can be gained which can be applied to the manufacturing sector (i.e. through servitization).

Finally, the impact of spontaneity on performance may be contingent on the type of decision made spontaneously. More specifically, making spontaneous tactical or day-to-day decisions may be productive, but doing so in the case of more complex decisions may not. Thus, future research may wish to contextualize spontaneity in terms of the type of decision made.

\section{References}

Agility Consulting and Training (2016), available at: http://agilityconsulting.com/ (accessed March 18, 2016).

Aiken, L. and West, S.G. (1991), Multiple Regression: Testing and Interpreting Interactions. Sage Publications, Thousand Oaks, CA.

Anderson, J.C. and Gerbing, D.W. (1988), "Structural equation modeling in practice: A review and recommended two-step approach”, Psychological Bulletin, Vol. 103 No. 3, pp. 411-423. 
Antioco, M., Moenaert, R.K., Lindgreen, A. and Wetzels, M.G.M. (2008), “Organizational antecedents to and consequences of service business orientations in manufacturing companies", Journal of the Academy of Marketing Science, Vol. 36 No. 3, pp. 337-358.

Antonakis J., Bendahan, S., Jacquart, P. and Lalive, R. (2010), “On making causal claims: A review and recommendations”, Leadership Quarterly, Vol. 21 No. 6, pp. 1086-1120.

Auh, S. and Menguc, B. (2007), "Performance implications of the direct and moderating effects of centralization and formalization on customer orientation", Industrial Marketing Management, Vol. 36 No. 8, pp. 1022-1034.

Bailey, A., Johnson, G. and Daniels, K. (2000), "Validation of a multi-dimensional measure of strategy development processes”, British Journal of Management, Vol. 11 No. 2, pp. 151162.

Bello, D.C., Katsikeas, C.S. and Robson, M.J. (2010), "Does accommodating a self-serving partner in an international marketing alliance pay off?" Journal of Marketing, Vol. 74 No. 6, pp. 77-93.

Berg, N. (2014), “Success from satisficing and imitation: Entrepreneurs' location choice and implications of heuristics for local economic development”, Journal of Business Research, Vol. 67 No. 8, pp. 1700-1709.

Boso, N., Story, V.M., Cadogan, J.W., Micevski, M. and Kadić-Maglajlić, S. (2013), "Firm innovativeness and export performance: Environmental, networking and structural contingencies", Journal of International Marketing, Vol. 21 No. 4, pp. 62-87.

Bourgeois, L.J., McAllister, D.W. and Mitchell, T.R. (1978), “The effects of different organizational environments upon decisions about organizational structure", Academy of Management Journal, Vol. 21 No. 3, pp. 508-514. 
Brown, S.L. and Eisenhardt, K.M. (1998), Competing on the Edge: Strategy as Structured Chaos. Harvard Business School Press, Cambridge, MA.

Busenitz, L.W., and Barney, J.B. (1997), “Differences between entrepreneurs and managers in large organizations: Biases and heuristics in strategic decision-making”, Journal of Business Venturing, Vol. 12 No. 1, pp. 9-30.

Cadogan, J.W., Cui, C.C. and Yeung Li, E.K. (2003), "Export market-oriented behavior and export performance", International Marketing Review, Vol. 20 No. 5, pp. 493-513.

Cadogan, J.W., Kuivalainen, O. and Sundqvist, S. (2009), "Export Market-Oriented Behavior and Export Performance: Quadratic and Moderating Effects Under Differing Degrees of Market Dynamism and Internationalization", Journal of International Marketing, Vol. 17 No. 4, pp. 71-89.

Cadogan, J.W., Paul, N.J., Salminen, R.T., Puumalainen, K. and Sundqvist, S. (2001), “Key antecedents to 'export' market-oriented behaviors: A cross-national empirical examination”, International Journal of Research in Marketing, Vol. 18, pp. 261-282.

Cadogan, J.W., Sundqvist, S., Salminen, R.T. and Puumalainen, K. (2005), “Export marketing, interfunctional interactions, and performance consequences", Journal of the Academy of Marketing Science, Vol. 33 No. 4, pp. 520-535.

Chandler, A.D. (1962), Strategy and Structure. MIT Press, Cambridge, MA.

Chelariu, C., Johnston, W.J. and Young, L. (2002), “Learning to improvise, improvising to learn: A process of responding to complex environments", Journal of Business Research, Vol. 55 No. 2, pp. 141-147.

Da Cunha, J.V., Pina E Cunha, M. and Faia Correia, M. (2001), "Scenarios for improvisation: Long range planning redeemed”, Journal of General Management, Vol. 27 No. 2, pp. 67-80. 
Dew N., Read, S., Sarasvathy, S.D. and Wiltbank, R. (2009), "Effectual versus predictive logics in entrepreneurial decision-making: Differences between experts and novices", Journal of Business Venturing, Vol. 24 No. 4, pp. 287-309.

Diamantopoulos, A. and Schlegelmilch, B.B. (1997), Taking the Fear out of Data Analysis, Dryden, London.

Diamantopoulos, A. and Siguaw, J. (2009), Introducing LISREL, Sage Publications, London.

Dibben, M., Harris, S. and Wheeler, C. (2003), "Export market development: Planning and relationship processes of entrepreneurs in different countries”, Journal of International Entrepreneurship, Vol. 1 No. 4, pp. 383-403.

Dibrell, C., Down, J. Bull, L. (2007), “Dynamic strategic planning: Achieving strategic flexibility through formalization”, Journal of Business and Management, Vol. 13 No. 1, pp. 21-36.

Dillman, D.A. (2000), Mail and Internet Surveys: The Tailored Design Method, Wiley, New York.

Donaldson, L. (2001), The Contingency Theory of Organizations, Sage Publications, Thousand Oaks, CA.

Fornell, C. and Larcker, D.F. (1981), "Evaluating structural equation models with unobservable variables and measurement error”, Journal of Marketing Research, Vol. 18 No. 1, pp. 39-50.

Germann, F., Lilien, G.L. and Rangaswamy, A. (2013), “Performance implications of deploying marketing analytics”, International Journal of Research in Marketing, Vol. 30 No. 2, pp. $114-128$.

Gesell, I. (2005), "Practiced spontaneity: Using improv theater skills to help teams master change", The Journal for Quality and Participation, Vol. 28 No. 1, pp. 4-7.

Gruber, M. (2007), "Uncovering the value of planning in new venture creation: A process and contingency perspective", Journal of Business Venturing, Vol. 22 No. 6, pp. 782-807. 
Hambrick, D.C. and Lei, D. (1985), “Toward an empirical prioritization of contingency Variables for business strategy", Academy of Management Journal, Vol. 28 No. 4, pp. 763-788.

Han, J.K., Kim, N. and Srivastava, R.K. (1998), "Market orientation and organizational performance: Is innovation a missing link?”, Journal of Marketing, Vol. 62 No. 4, pp.30-45.

Hmieleski, K.M., Corbett, A.C. and Baron R.A. (2013), “Entrepreneurs improvisational behavior and firm performance: A study if dispositional and environmental moderators", Strategic Entrepreneurship Journal, Vol. 7 No. 2, pp. 138-150.

Hofer, C.W. (1975), “Toward a contingency theory of business strategy”, Academy of Management Journal, Vol. 18 No. 4, pp. 784-810.

Hultman, M., Katsikeas, C.S. and Robson, M.J. (2011), “Export promotion strategy and performance: The role of international experience", Journal of International Marketing, Vol. 19 No. 4, pp. 17-39.

Hultman, M., Robson, M.J. and Katsikeas, C.S. (2009), "Export product strategy fit and performance: An empirical investigation”, Journal of International Marketing, Vol. 17 No. 4, pp. 1-23.

Jaccard, J. and Wan, C.K. (1996), LISREL Approaches to Interaction Effects in Multiple Regression, Sage Publications, Thousand Oaks, CA.

Jaworski, B.J. and Kohli, A.K. (1993), "Market orientation: Antecedents and consequences”, Journal of Marketing, Vol. 57 No. 3, pp. 53-70.

Jöreskog, K. and Sörbom, D. (1993), LISREL 8: Structural Equation Modeling with the SIMPLIS Command Language, Scientific Software International, Hillsdale, NJ.

Kam, C.K. and Franzese Jr., R.J. (2007), Modeling and Interpreting Interaction Hypotheses in Regression Analysis, MI: The University of Michigan Press. 
Katsikea, E., Theodosiou, M. and Morgan, R.E. (2007), “Managerial, organizational, and external drivers of sales effectiveness in export market ventures", Journal of the Academy of Marketing Science, Vol. 35 No. 2, pp. 270-283.

Katsikeas, C.S., Leonidou, L.C. and Morgan, N.A. (2000), "Firm-level export performance assessment: Review, evaluation, and development", Journal of the Academy of Marketing Science, Vol. 28 No. 4, pp. 493-511.

Knight, G.A. and Liesch, P.W. (2016), "Internationalization: From incremental to born global”, Journal of World Business, Vol. 51 No. 1, pp. 93-102.

Langerak, F., Hultink, E.J. and Robben, H.S.J. (2004), “The impact of market orientation, product advantage, and launch proficiency on new product performance and organizational performance”, Journal of Product Innovation Management, Vol. 21 No. 2, pp. 79-94.

Leybourne, S.A. (2006), "Managing change by abandoning planning and embracing improvisation”, Journal of General Management, Vol. 31 No. 3, pp. 11-29.

Lukas, B.A., Whitwell, G.J. and Hill, P. (2007), "Export planning orientation and its antecedents: Evidence from exporting IT products”, Journal of Business Research, Vol. 60 No. 12, pp. 1282-1289.

Mascitelli, R. (2000), "From experience: Harnessing tacit knowledge to achieve breakthrough innovation”, Journal of Product Innovation Management, Vol. 17 No. 3, pp. 179-193.

Menon, A., Bharadwaj, S.G. and Howell, R. (1996), “The quality and effectiveness of marketing strategy: Effects of functional and dysfunctional conflict in intraorganizational relationships", Journal of the Academy of Marketing Science, Vol. 24 No. 4, pp.299-313. Mintzberg, H. (1978), "Patterns in strategy formation,” Management Science, Vol. 24 No. 9, pp. 934-948. 
Moorman, C. and Miner, A.S. (1998), "The convergence of planning and execution: Improvisation in new product development”, Journal of Marketing, Vol. 62 No. 3, pp. 1-20.

Nemkova, E., Souchon, A.L. and Hughes, P. (2012), "Export decision-making orientation: An exploratory study", International Marketing Review, Vol. 29 No. 4, pp. 349-378.

Nemkova, E., Souchon, A.L., Hughes, P. and Micevski, M. (2015), “Does improvisation help or hinder planning in determining export success? Decision theory applied to exporting”, Journal of International Marketing, Vol. 23 No. 3, pp. 41-65.

Nummela, N., Saarenketo, S., Jokela, P. and Loane, S. (2014), "Strategic decision-making of a Born Global: A comparative study from three small open economies”, Management International Review, Vol. 54 No. 4, pp. 527-550.

Nutt, P.C. (2008), "Investigating the success of decision making processes", Journal of Management Studies, Vol. 45 No. 2, pp. 425-455.

Olson, P.D. (1986), “Entrepreneurs: Opportunistic decision makers”, Journal of Small Business Management, Vol. 24 July, pp. 29-35.

Pina E Cunha, M. (2007), “Entrepreneurship as decision making: rational, intuitive and improvisational approaches", Journal of Enterprising Culture, Vol. 15 No. 1, pp. 1-20.

Pina E Cunha, M., Kamoche, K. and Campos E Cunha, R. (2003), “Organizational improvisation and leadership: A field study in two computer-mediated settings", International Studies of Management and Organization, Vol. 33 No. 1, pp. 34-57.

Ping, R.A. (1995), “A parsimonious estimating technique for interaction and quadratic latent variables", Journal of Marketing Research, Vol. 32 August, pp. 336-347.

Podsakoff, P.M., MacKenzie, S.B., Lee, J.-Y. and Podsakoff, N.P. (2003), “Common method biases in behavioral research: A critical review of the literature and recommended remedies", Journal of Applied Psychology, Vol. 88 No. 5, pp. 879-903. 
Raven, P.V., McCullough, J.M. and Tansuhaj, P.S. (1994), “Environmental influences and decision-making uncertainty in export channels: Effects on satisfaction and performance”, Journal of International Marketing, Vol. 2 No. 3, pp. 37-59.

Rindfleisch, A., Malter, A.J., Ganesan, S. and Moorman, C. (2008), “Cross-sectional versus longitudinal survey research: Concepts, findings, and guidelines", Journal of Marketing Research, Vol. 45 No. 3, pp. 261-279.

Ruekert, R.W., Walker, Jr., O.C. and Roering, K.J. (1985), “The organization of marketing activities: A contingency theory of structure and performance", Journal of Marketing, Vol. 49 No. 1, pp. 13-26.

Sharma, S., Durand, R.M. and Gur-Arie, O. (1981), "Identification and analysis of moderator variables", Journal of Marketing Research, Vol. 18 No. 3, pp. 291-300.

Simon, H.A. (1957), Models of Man - Social and Rational, John Wiley \& Sons, New York. Sirmon, D.G. and Hitt, M.A. (2008), “Contingencies within dynamic managerial capabilities: Interdependent effects of resource investment and deployment on firm performance", Strategic Management Journal, Vol. 30 No. 13, pp. 1375-1394.

Song, M., Droge, C., Hanvanich, S. and Calantone, R. (2005), "Marketing and technology resource complementarity: An analysis of their interaction effect in two environmental contexts", Strategic Management Journal, Vol. 26 No. 3, pp. 259-276.

Souchon, A.L., Sy-Changco, J.A. and Dewsnap, B. (2012), "Learning orientation in export functions: impact on export growth”, International Marketing Review, Vol. 29 No. 2, pp. $175-202$.

Sousa, C.M.P. (2004), "Export performance measurement: An evaluation of the empirical research in the literature", Academy of Marketing Science Review 9 [available from http://amsreview.org/articles/sousa09-2004.pdf] 
Sousa, C.M.P., Martínez-López, F. and Coelho, F. (2008), “The determinants of export performance: A review of the research in the literature between 1998 and 2005”, International Journal of Management Reviews, Vol. 10 No. 2, pp. 343-374.

Tayur, S.R. (2013), "Planned spontaneity for better product availability”, International Journal of Production Research, Vol. 51 No. 23-24, pp. 6844-6859.

Theodosiou, M. and Katsikea, E. (2013), “The export information system: An empirical investigation of its antecedents and performance outcomes”, Journal of International Marketing, Vol. 21 No. 3, pp. 72-94.

Varadarajan, P.R. and Jayachandran, S. (1999), "Marketing strategy: An assessment of the state of the field and outlook", Journal of the Academy of Marketing Science, Vol. 27 No. 2, pp. $120-143$.

Venkatraman, N. (1989), “The concept of fit in strategy research - Toward verbal and statistical correspondence”, Academy of Management Review, Vol. 14 No. 3, pp. 423-444.

Vera, D. and Crossan, M. (2005), "Improvisation and innovative performance in teams", Organization Science, Vol. 16 No. 3, pp. 203-224.

Vorhees, C., Brady, M.K., Calantone, R. and Ramirez, E. (2016), “Discriminant validity testing in marketing: An analysis, causes for concern, and proposed remedies", Journal of the Academy of Marketing Science, Vol. 44 No. 1, pp. 119-134.

Weick, K.E. (1998), “Improvisation as a mindset for organizational analysis”, Organization Science, Vol. 9 No. 5, pp. 543-556.

Zahra, S.A., and Garvis, D.M. (2000), "International corporate entrepreneurship and firm performance: The moderating effect of international environmental hostility", Journal of Business Venturing, Vol. 15 No. 5, pp. 469-492. 
Table 1 Model Fit Indicators, Correlation Matrix, and Scale Properties

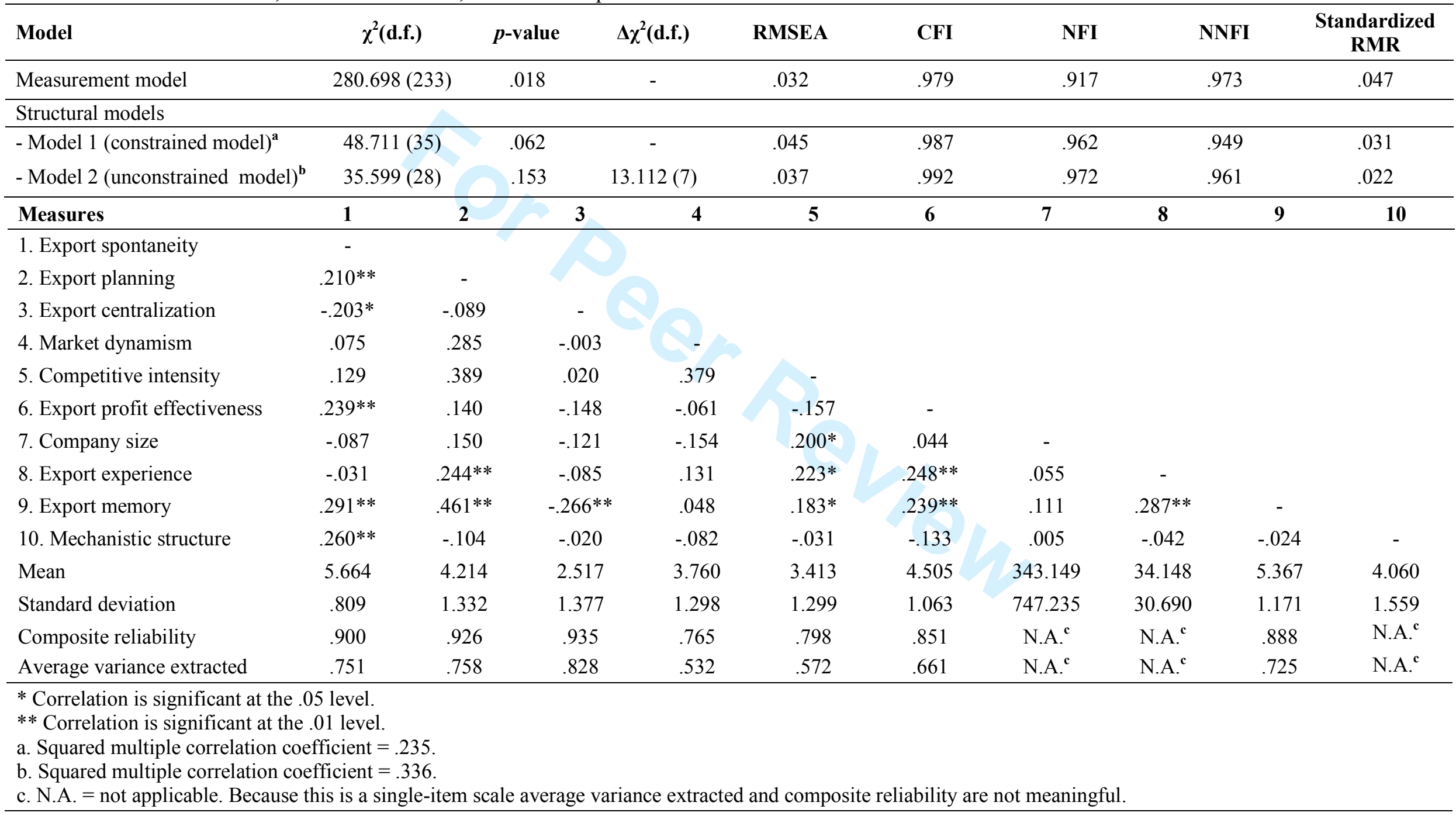


25

26

28

29

30

32

33

34

35
36

37

38

39

40

41

43

44

45

46

47

48

49

51

52

54

55

57

58

59

60 \\ Page 31 of 38}

International Marketing Review

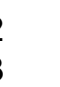

5

7

10

12

3

(8)

1


Table 2 Model Path Coefficients and T-values

Parameter Estimates and t-Values ${ }^{a}$

\section{Hypotheses Supported by Path}

\begin{tabular}{|c|c|c|c|}
\hline \multirow[t]{2}{*}{$\mathrm{H}_{1}$} & Export spontaneity & .293 & 2.716 \\
\hline & Export spontaneity squared & -.041 & -.216 \\
\hline \multirow[t]{2}{*}{$\mathrm{H}_{2}$} & Export spontaneity $\mathrm{x}$ export planning & .199 & 1.180 \\
\hline & Export spontaneity squared $\mathrm{x}$ export planning & .405 & 2.175 \\
\hline \multirow[t]{2}{*}{$\mathrm{H}_{3}$} & Export spontaneity x export centralization & -.079 & -.638 \\
\hline & Export spontaneity squared $\mathrm{x}$ export centralization & .239 & 1.815 \\
\hline \multirow[t]{2}{*}{$\mathrm{H}_{4}$} & Export spontaneity $\mathrm{x}$ market dynamism & -.324 & -2.107 \\
\hline & Export spontaneity squared x market dynamism & -.230 & -1.535 \\
\hline \multicolumn{4}{|c|}{ Controls } \\
\hline & Export planning & .105 & .996 \\
\hline & Export centralization & .007 & .091 \\
\hline & Market dynamism & -.009 & -.084 \\
\hline & Competitive intensity & -.361 & -3.239 \\
\hline & Company size & .096 & .951 \\
\hline & Export experience & .291 & 3.015 \\
\hline
\end{tabular}




\section{Page 33 of 38}

International Marketing Review

11

2
3
4
5
6
7
8
9
10
11
12
13
14
15
16
17
18
19
20
21
22
23
24
25
26
27
28
29
30
30
31
32
33
34
35
35
36
37
38
39
40
4
4
42
43
44
45
47
48
49

2
3
4
5
6
7
8
9
10
11
12
13
14
15
16
17
18
19
20
21
22
23
24
25
26
27
28
29
30
30
31
32
33
34
34
35
36
37
38
39
39
40
41
42
43
44
45
46
47
49

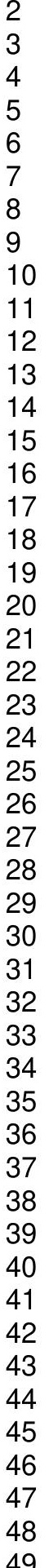

2
3
4
5
6
7
8
9
10
11
12
13
14
15
16
17
18
19
20
21
22
23
24
25
26
27
28
29
30
30
31
32
33
34
34
35
36
37
38
39
39
40
41
42
43
44
45
46
47
49

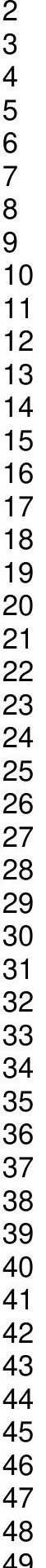

19

2
3
4
5
6
7
8
9
10
11
12
13
14
15
16
17
18
19
20
21
22
23
24
25
26
27
28
29
30
30
31
32
33
34
34
35
36
37
38
39
39
40
41
42
43
44
45
46
47
49

2
3
4
5
6
7
8
9
10
11
12
13
14
15
16
17
18
19
20
21
22
23
24
25
26
27
28
29
30
30
31
32
33
34
35
35
36
37
38
39
40
4
4
42
43
44
45
47
48
49

23

2
3
4
5
6
7
8
9
10
11
12
13
14
15
16
17
18
19
20
21
22
23
24
25
26
27
28
29
30
30
31
32
33
34
34
35
36
37
38
39
39
40
41
42
43
44
45
46
47
49

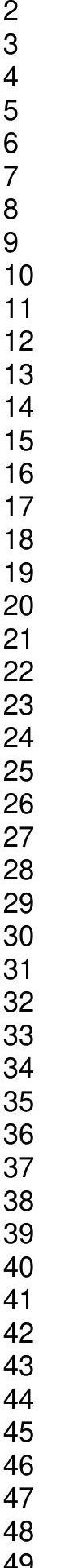

2
3
4
5
6
7
8
9
10
11
12
13
14
15
16
17
18
19
20
21
22
23
24
25
26
27
28
29
30
31
32
33
34
35
36
37
38
39
40
41
42
43
44
45
46
47
48
49

30

31

32

34
35

36

37

38
39

2
3
4
5
6
7
8
9
10
11
12
13
14
15
16
17
18
19
20
21
22
23
24
25
26
27
28
29
30
31
32
33
34
35
36
37
38
39
40
41
42
43
44
45
46
47
48
49

41

44

45

46

48

2
3
4

8

(3)


Table 3 Items, factor loadings and error variances

Items and examples of item sources

Export Spontaneity ${ }^{\text {a }}$ (Vera and Crossan, 2005)

Member(s) of the export function ... are good at thinking on their feet when carrying out actions $\quad .822 \quad .324$

$\ldots$ are able to deal with unanticipated events on the spot

... have an ability to respond "in the moment" to unexpected problems

Export Planning $^{\text {a }}$ (Bailey et al., 2000)

We meticulously assess many alternatives when deciding on an export decision

We evaluate potential strategic export options against explicit export objectives

We have definite and precise strategic export objectives

Completely

standardized

loadings

(Lambda-X)

We make export decisions based on a systematic analysis of our export environment

Export Centralization ${ }^{a}$ (Cadogan et al., 2005)

Even small export matters have to be referred to top management for a final answer

Approval by top management has to be sought before anything can get done

Any export decision made has to be approved by top management

Market Dynamisma (Jaworski and Kohli, 1993)

New export customers tend to have product-related needs that are different from those of our existing export customers

Our export customers' product preferences change quite a bit over time

Our export customers tend to look for new products all the time

Competitive Intensity ${ }^{\text {a }}$ (Jaworski and Kohli, 1993)

In our export markets, there are many "promotion wars"

One hears of a new competitive move in our export markets almost every day

In our foreign markets, aggressive selling is the norm
.929

.844

.136

Error

variances

(Theta-

Delta)

324

.288

.824

.902

.871

.883

.187

.241

.220

$\begin{array}{ll}.889 & .209 \\ .958 & .082 \\ .880 & .226\end{array}$




\section{Table III continued}

\begin{tabular}{|c|c|c|}
\hline Items and examples of item sources & $\begin{array}{l}\text { Completely } \\
\text { standardized } \\
\text { loadings } \\
\text { (Lambda-X) }\end{array}$ & $\begin{array}{l}\text { Error } \\
\text { variances } \\
\text { (Theta- } \\
\text { Delta) }\end{array}$ \\
\hline \multicolumn{3}{|l|}{ Export Profit Effectiveness (Cadogan et al., 2005; Langerak et al.,2004) } \\
\hline $\begin{array}{l}\text { Please indicate how well your export products have performed over the last three years in terms of... } \\
\ldots \text { meeting profitability goals }{ }^{\mathrm{b}} \\
\ldots \text { meeting contribution margin goals } \\
\text { Overall, how profitable has exporting been over the last year? }^{\mathrm{c}}\end{array}$ & $\begin{array}{l}.863 \\
.912 \\
.637\end{array}$ & $\begin{array}{l}.255 \\
.169 \\
.594\end{array}$ \\
\hline Export Memory $^{\text {a }}$ (Souchon et al., 2012) & & \\
\hline $\begin{array}{l}\text { The export team/person... } \\
\ldots \text { has an abundance of export knowledge } \\
\ldots \text { has current knowledge about export matters } \\
\ldots \text { has a rich memory base }\end{array}$ & $\begin{array}{l}.869 \\
.846 \\
.839\end{array}$ & $\begin{array}{l}.245 \\
.284 \\
.297\end{array}$ \\
\hline
\end{tabular}

\section{Mechanistic Structure $^{\mathrm{d}}$ (Bourgeois et al., 1978)}

We strongly emphasize always getting personnel to follow the formally laid down procedures/Things get done even if this means disregarding formal procedures

NOTE: (R) Item reverse coded for analysis purposes

a 7 -point scale with anchors strongly disagree/strongly agree

b 7-point scale with anchors very poor/outstanding

c 7-point scale with anchors very unprofitable/very profitable

d 7-point bipolar scale 
Figure 1. Conceptual framework

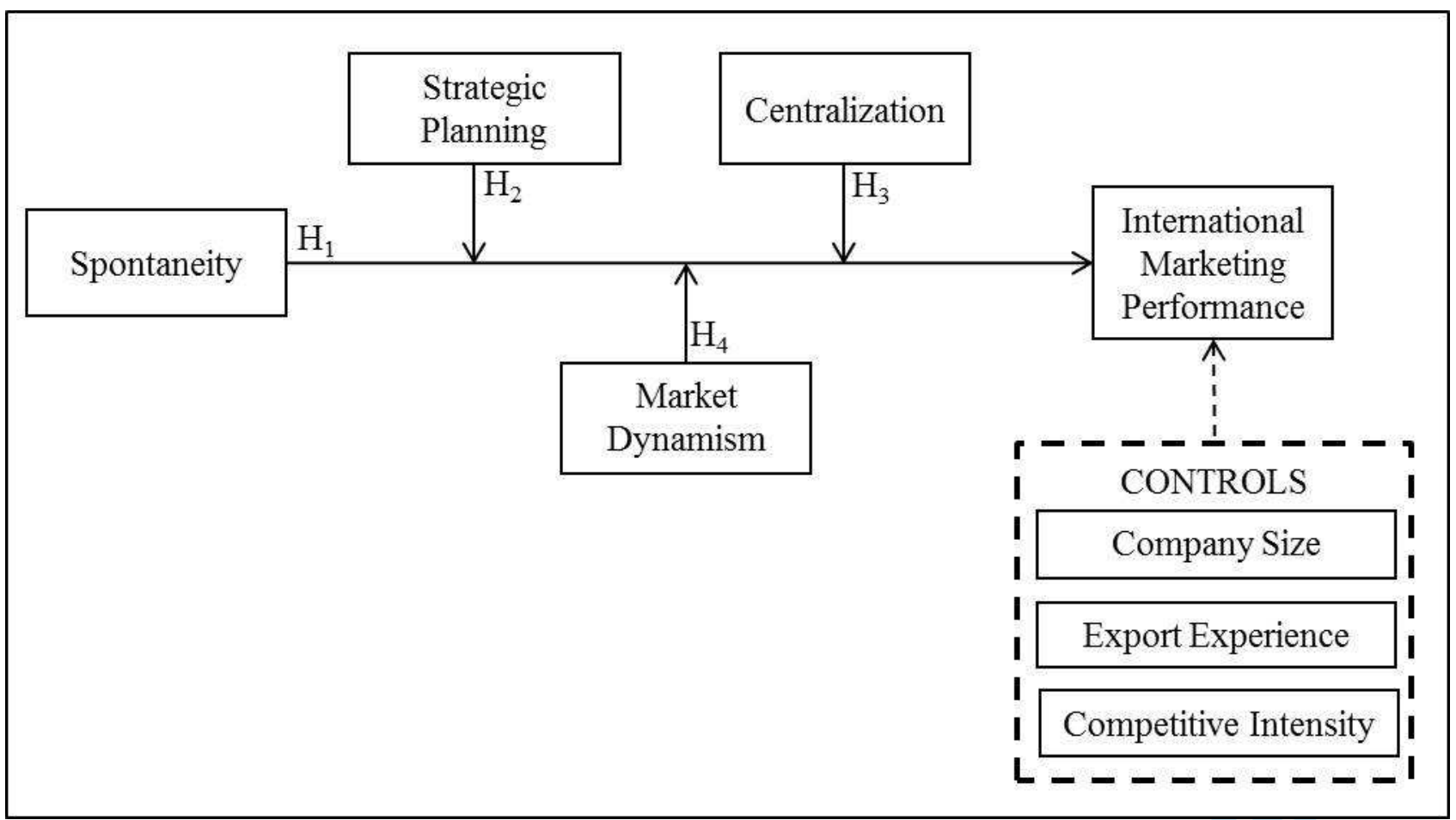


25

26

28

29

30

32

33

34

35
36

37

38

39

40

41

42
43

44

45

46

47

48

49

51

52

53

54

55

57

58

59

60 \\ Page 37 of 38}

International Marketing Review

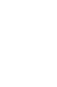

5

7

10

1

3

(8)

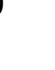

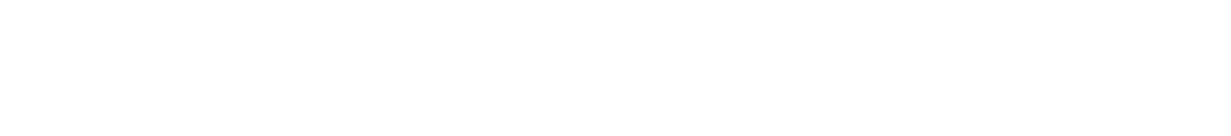


Figure 2. Spontaneity-performance link under low and high values of moderators

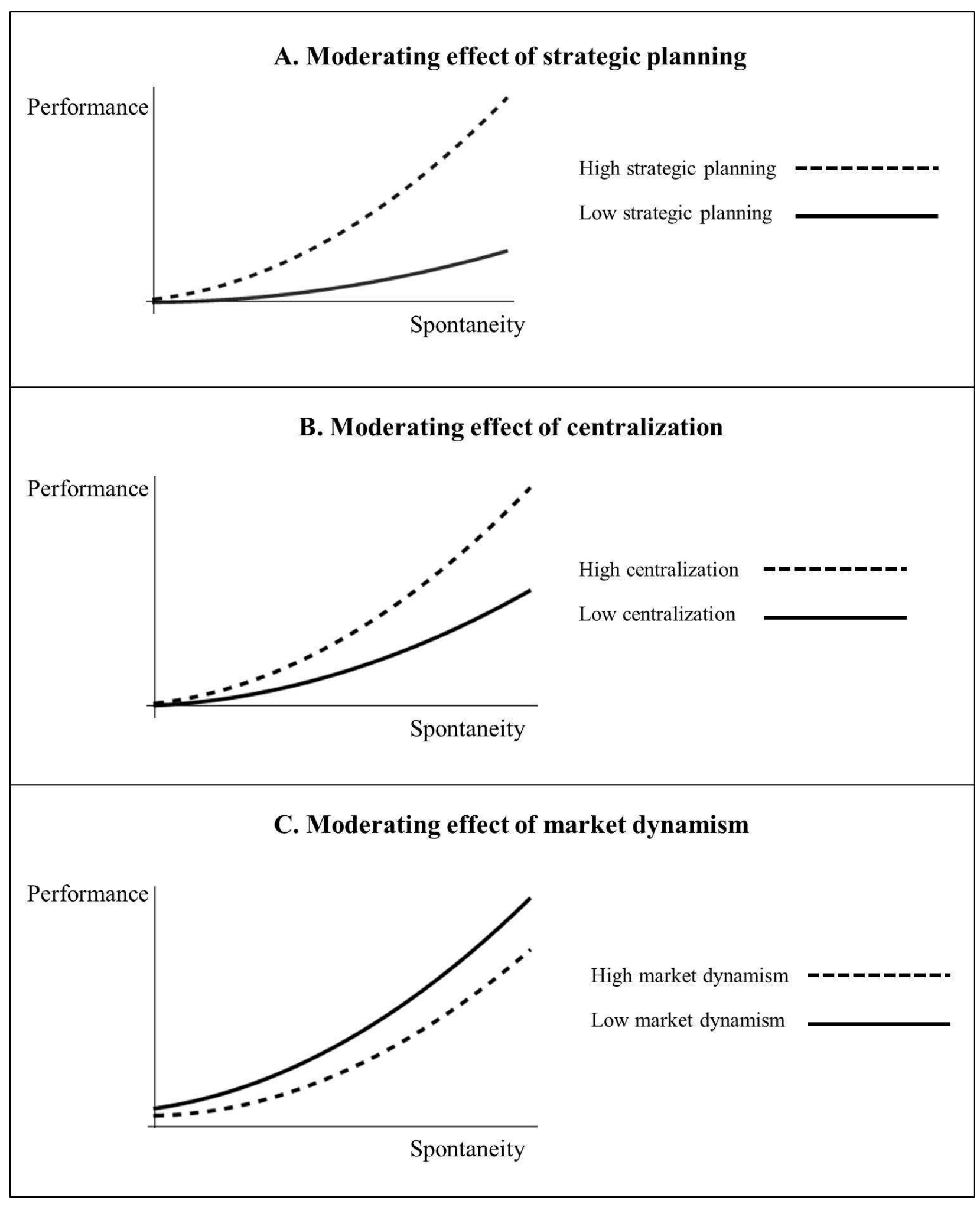

